\title{
Notes on the new international estimates of energy requirements
}

\author{
By J. C. Waterlow, London School of Hygiene and Tropical Medicine, Keppel \\ Street, London $W C \mathrm{I} E{ }_{7} H T$
}

In the present paper I shall try to discuss the ideas and principles underlying the estimates of human energy requirements proposed by a consultative group set up by the Food and Agriculture Organization, World Health Organization and United Nations University, that met in Rome in October 1981 (FAO/WHO/UNU, 1985). I shall only consider adults, since Whitehead (1986) discusses the requirements of infants and young children.

\section{Intake v. expenditure}

In the present report, estimated energy requirements are based more firmly than before on measurements of energy expenditure rather than of intake. An exception is in infants and children up to the age of to years, whose requirements are estimated from intakes because we do not know enough about their expenditure.

The principle is not new, but it has been applied more rigorously than before. Of course, if people are in balance, maintaining constant body-weight, input and output will, over the long term, be equal, and it should not matter which is measured to give an estimate of energy requirement. Without embarking on the difficult question of whether energy balance is maintained through regulation of input or output or both, it seems to me common sense that because we have to expend energy, we need an intake, rather than the other way round. Thus expenditure is the primary factor.

The word 'requirement', as generally used in relation to healthy people, refers to the habitual requirement over a period of time; a period that admittedly has not been specified. Requirement over 1 or $2 \mathrm{~d}$ makes no sense, except perhaps in people who are ill and whose state is rapidly changing. However, both intakes and outputs are usually measured over quite short periods of a few days on a finite number of subjects. The measurements, therefore, can only produce estimates of what is habitual and, because of the variation within and between individuals, they may be very much in error. Moreover, as is well known, even with the most careful technique, estimates of energy intake and output frequently do not agree (e.g. Norgan et al. 1974). There is in fact no reason to suppose that over the short term people do maintain an exact energy balance. Even if there are no changes in weight, alterations in body composition may occur that are too small to be detected by the methods currently available. For these reasons, in interpreting measurements of intake and output, it is important to have some idea of their variability. 
Table I. Between-subject variability of energy intake and expenditure in subjects studied over 5 d or more*

$\begin{array}{llrc} & & \text { No. } & \text { Mean CV (\%) } \\ \text { Intake: } & \text { Men } & 145^{8} & 14.8 \\ \text { Expenditure: } & \text { Women } & 2247 & 18.3 \\ & \text { Men } & 218 & 10.8 \\ & \text { Women } & 99 & 10.8 \\ & & \\ & \text { CV, coefficient of variation. } & \\ & \text { 'From Harries } \text { et al. (1962). }\end{array}$

\section{Variability}

The huge range of intakes of apparently similar people has often been stressed. Harries et al. (1962) collected the results of earlier surveys and their findings are summarized in Table 1. Sukhatme \& Margen (1982) were perhaps the first to point out that much of this variability, even when measurements are made over $7 \mathrm{~d}$ or more, as in most of the studies reported by Harries et al. (1962), represents variation within each individual. Their analysis of the study on army cadets made by Edholm et al. (1970) showed that there was a very large within-subject variation from day-to-day, and even larger variation from week-to-week. In a study in Canada (Beaton et al. I979), intakes were measured for I d on six occasions in I year. The total variability was about $35 \%$; the variation both within and between subjects was about $25 \%$.

Energy expenditure is clearly more difficult to measure than intake, but when it has been measured accurately it is less variable than intake both within and between subjects (see Table I). The results of Booyens \& McCance (1957) illustrate these points very well (Table 2). The first point is that intake and output over $\mathrm{I}-2$ weeks were, on average, in good agreement, although, as mentioned previously, this has certainly not always been found. Second, the range of variation, both within and between subjects, was smaller for output than for intake. The subjects of Booyens \& McCance (1957) were living their normal lives. In the highly controlled conditions of a fixed pattern of activity in a whole-body calorimeter, the variability appears to be much less. The within-subject coefficient of variation

Table 2. Within-subject variability of energy intake and expenditure (summarized from Booyens \& McCance, 1957)

(Values are means with their standard errors for six subjects studied over 7-14 d)

$\overbrace{\substack{\text { Mean } \\ I .00}}^{\text {Expenditure/intake }}$

Range of day-to-day variation: maximum/minimum

$\overbrace{\substack{\text { Mean } \\ 1.26}}^{\text {Expenditure }} \overbrace{\substack{\text { Mean } \\ 0.14}}^{\text {Intake }}$


(CV) of energy expenditure is about $2 \%$ (Dallosso et al. 1982; Garby \& Lammert, 1984) and the CV between subjects about 6\% (Garby et al. 1986). The lower variability is a further reason for basing requirements on energy expenditure rather than intake.

\section{Basal metabolic rate (BMR)}

Except for the minority of people who habitually do very heavy physical work, the largest component of the total energy expenditure is the BMR. Durnin (198I) made a very comprehensive review of the literature on BMR, but some problems remained about the requisite equations for its prediction for a person of given sex, age and body size. An analysis of the world literature by Schofield et al. (1985) resulted in a series of linear equations relating expected BMR to body-weight. There are separate equations for the two sexes and for six age-ranges $(0-3,3-10$, 10-18, 18-30, 30-60 and over 60 years), corresponding more or less to the physiological ages of man as described by William Shakespeare. The addition of variables such as height or surface area, and expressions such as power functions, were tested but did not improve the precision of prediction, which is about $\pm 7-10 \%$ for a single individual and much less for the mean of a group. In view of the concentration in the past on surface area as the appropriate basis for expressing the BMR, it is surprising that including height in the equations made no difference to the precision of prediction. This means that, within the range covered by the experimental values, the expected BMR of two people of the same age, sex and weight will be the same, even though one is tall and thin and the other short and plump; this is very convenient.

The equations show that the BMR/kg increases with decreasing body-weight. Thus at $70 \mathrm{~kg}$, the expected BMR for a young man is $104.5 \mathrm{~kJ} / \mathrm{kg}$ and at $55 \mathrm{~kg}$ it is $115.4 \mathrm{~kJ} / \mathrm{kg}$, an increase of nearly ro\%. I should emphasize that these linear equations are simply descriptions of the experimental values; they do not claim to have physiological meaning. If we take the two BMR values quoted previously and relate them to body-weight ${ }^{2} / 3$, they are almost identical $(426$ and $435 \mathrm{~kJ} / \mathrm{kg}$ body-weight $2 / 3$ ). Thus the new report has in effect abandoned the position taken up by its predecessor (FAO/WHO, 1973) that BMR/kg is constant for people of a given age and sex, and gone back to the older concept that BMR varies as a power function of body-weight.

\section{Physical activity}

An important innovation is that the energy cost of activities is now expressed as a multiple of BMR. Thus the FAO/WHO/UNU (1985) group worked out some examples of the activities and the times spent on them by typical groups of people and, using the old values of Passmore \& Durnin (1955) for the energy costs of those activities, came up with calculations of total energy expenditure as a multiple of BMR. One example is shown in Table 3. Table 4 gives the estimated average energy expenditure of the two sexes at different levels of activity. The effect of these calculations is to increase the estimated expenditure and hence requirement 


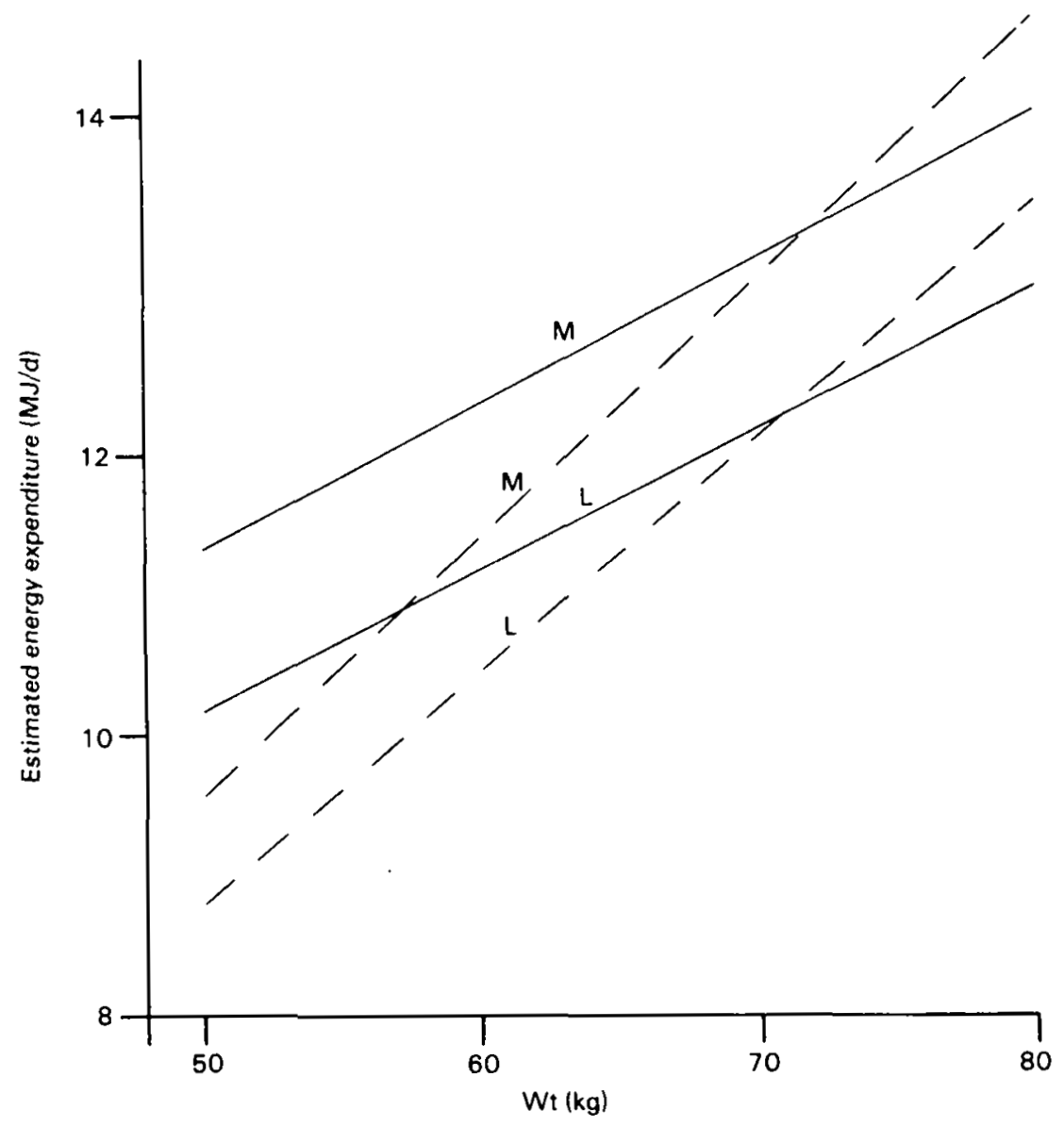

Fig. 1. Estimated energy requirement in relation to body-weight. Comparison of Food and Agriculture Organization/World Health Organization (1973) (-- - ) and Food and Agriculture Organization/World Health Organization/United Nations University (1985) (-) estimates. M, moderate activity; L, light activity.

of light people and to decrease that of heavy people, compared with the FAO/WHO (1973) estimates (Fig. 1).

The approach adopted assumes that the energy cost of physical activity is related to body-weight in the same way as the BMR. For many ordinary activities that involve moving the body the assumption is probably justified. For example, McDonald (Annex 3 of FAO/WHO/UNU, 1985) showed that the energy cost of walking on a treadmill at different speeds, when expressed as a multiple of BMR, is the same over a range of body-weights from 50 to $80 \mathrm{~kg}$. However, there are situations where the assumption may not hold, as in lifting heavy weights other than the body. The ratio total energy expenditure:BMR has been called the physical activity index (PAI). Garby et al. (1986) have studied subjects doing fixed programmes of moderate physical activity over $24 \mathrm{~h}$ in a calorimeter and shown 
Table 3. Estimated energy requirement of a subsistence farmer

$\begin{array}{lccc} & \text { PAI } \times \text { BMR } & \begin{array}{c}\text { Period of } \\ \text { time }(\mathrm{h})\end{array} & \begin{array}{c}\text { Expenditure } \\ (\mathbf{k J})\end{array} \\ \text { In bed } & \mathbf{1} \cdot 0 & 8 & 2170 \\ \text { Occupational activities } & 2 \cdot 7 & 7 & 5150 \\ \text { Discretionary activities } & 3 \cdot 0 & 2 & 1630 \\ \text { Residual time } & 1 \cdot 4 & 7 & 2680 \\ & & \text { Total } & 11630 \\ & & & (1 \cdot 78 \times \text { BMR) }\end{array}$

PAI, physical activity index; BMR, basal metabolic rate.

-From Food and Agriculture Organization/World Health Organization/United Nations University ( 1985 ).

that the inter-individual variability of PAI is much the same as that of BMR (6-8\%).

In discussing energy requirements the FAO/WHO/UNU (1985) group asked itself: 'requirements for what?' The answer was: to maintain health, physical activity and a satisfactory quality of life. The argument was that no one should be limited in their physical activity by an inadequate energy intake. There are many activities, additional to those needed for earning a living, that are beneficial to the individual or the community: games, cultivating the garden, walking to the welfare clinic, etc. These have been called 'discretionary activities' and a small allowance has been made for them in the new estimates of energy requirements (Table 3). Thus the FAO/WHO/UNU (1985) group felt that we should allow for more than the bare maintenance of life and working capacity. At the lowest level it was estimated that $\mathrm{I} \cdot 2 \mathrm{BMR}$ is the minimum needed to maintain life when all services are provided, as for someone in a refugee camp when supplies are minimal. A realistic 'maintenance' requirement would be I.4 BMR; this would allow for activities such as cooking and for walking about but not for any serious degree of physical activity.

It should be emphasized that the new report (FAO/WHO/UNU, 1985) does not make rigid prescriptions. It presents the user with choices and the values on which to base his choices. It says: if you are of this sex and this age, with this body-weight and this level of physical activity, we estimate that on average your requirements will be $X$. The user can reject the need for discretionary activity; he

Table 4. Average daily energy requirements expressed as multiples of basal metabolic rate

$\begin{array}{lccc}\text { Type of work ... } & \text { Light } & \text { Moderate } & \text { Heavy } \\ \text { Men } & 1 \cdot 55 & 1 \cdot 78 & 2 \cdot 10 \\ \text { Women } & 1 \cdot 5^{6} & 1 \cdot 64 & 1 \cdot 82\end{array}$

\footnotetext{
-From Food and Agriculture Organization/World Health Organization/United Nations Univer3ity (1985).
} 
can set his own values for appropriate body-weight and level of physical activity and make his calculations accordingly. I believe that this flexibility is an important advance.

It is probable that the new estimates of energy requirements, flexible though they are, will be regarded as too high, because in many surveys intakes appear to be appreciably lower than estimated requirements. I have already mentioned the inherent variability of intakes measured over a short period, which introduces great uncertainty into comparisons of intake and expenditure. Nevertheless, in many studies, particularly on pregnant and lactating women (e.g. Prentice, 1979) the discrepancies are so great that they can hardly be dismissed as artefacts. One explanation may be a tendency not only to underestimate intake but to overestimate expenditure when measured by the standard activity-diary method. For example, recent measurements by the labelled-water method in free-living Cambridge women (Prentice et al. 1985) have shown an average expenditure of $\mathrm{I} \cdot 3^{8} \mathrm{BMR}$, which is about equal to the estimated requirement for maintenance, whereas the $\mathrm{FAO} / \mathrm{WHO} / \mathrm{UNU}\left(\mathrm{rg}_{5}\right)$ estimate of the expenditure of a housewife in an affluent society was I. 52 BMR.

\section{Adaptation}

The discrepancies between intake and output lead on to the subject of adaptation. The most important adaptation is to have a small body size. Many but not all groups in developing countries are short in stature (Eveleth \& Tanner, 1976). It is probable that this is mainly determined by environmental and not by genetic factors (Satyanarayana et al. 1979; Martorell, 1985). When it comes to weight, it is not at all clear what is the lower limit in adults that is compatible with acceptable function. Statistics from the USA (Bray, 1979) suggest that at a body mass index (weight/height ${ }^{2}$; BMI) below 19 mortality risk begins to rise. This may well be an artefact of conditions of life in an industrialized society (Rhoads \& Kagan, 1983). In developing countries many people appear to be perfectly healthy with a lower BMI. From the information on famine collected by Keys et al. (1950), the lower limit compatible with life is probably a BMI of the order of 12-13. Anorexic women may be symptom-free and even hyperactive with a BMI of 14-15. I would provisionally accept 16 as the lower limit of acceptable BMI.

The next issue is the extent to which metabolic adaptations may be possible in subjects exposed all their lives to low-energy intakes. The BMR is the major component of energy expenditure. It has been known for many years, and has been confirmed by recent analysis (Schofield et al. 1985) that the BMR of Indians is lower than that of Caucasians. Shetty ( 1984 ) has studied poor Indian labourers who, with a BMI of only 16 , were nevertheless active and fit. These men had a BMR $17 \%$ below that predicted from the Schofield et al. (1985) equations (Table 5). It is interesting that the volunteers in the classical experiment of Keys et al. (1950), after 24 weeks of semi-starvation, had reached the same BMI but were in poor physical and psychological condition. Evidently that was not a long enough period for adaptation. 
Table 5. Effect of low body-weight on basal metabolic rate (BMR)

\begin{tabular}{|c|c|c|c|c|}
\hline & \multirow{2}{*}{$\begin{array}{l}\text { Indian } \\
\text { controlst }\end{array}$} & \multirow{2}{*}{$\begin{array}{c}\text { Indian } \\
\text { labourerst? }\end{array}$} & \multicolumn{2}{|c|}{ US volunteers $\ddagger$} \\
\hline & & & Initial & 24 weeks \\
\hline $\begin{array}{l}\text { Wt (kg) } \\
\text { Body mass index }\end{array}$ & $6 r \cdot 5$ & 46 & $68 \cdot 3$ & $5^{2}$ \\
\hline$\left(w t / h^{2} i g h t^{2}\right)$ & $20 \cdot 7$ & 16.6 & $2 I \cdot 4$ & $16 \cdot 3$ \\
\hline BMR: $\mathrm{kJ} / \mathrm{kg}$ & III & 105 & 97 & 81 \\
\hline $\begin{array}{l}\mathrm{kcal} / \mathrm{kg} \\
\% \text { observed/expected }\end{array}$ & $\begin{array}{l}26 \cdot 5 \\
100\end{array}$ & $\begin{array}{l}25 \cdot I \\
83\end{array}$ & $\begin{array}{l}23 \cdot 1 \\
91\end{array}$ & $\begin{array}{l}19 \cdot 35 \\
68\end{array}$ \\
\hline
\end{tabular}

One can envisage several possibilities to account for a fall in BMR on a low-energy intake, although all are still hypothetical. (1) Decreased work of the heart, since the Indian labourers (Table 5) had low pulse rates and blood pressures. This could save about $1 \%$ of basal expenditure. (2) Decreased rate of protein turnover. A reduction of $25 \%$, which is probably within the range of normal variation, would save about $3 \%$ of BMR. This hypothesis has not yet been tested, although it easily could be. (3) Much more difficult to measure is the possibility of decreased ion transport, i.e. of sodium-pump activity. If ion gradients are to be maintained, this would presumably involve a decrease in membrane permeability. (4) Alterations in metabolic pathways could make a significant contribution. For example, when glucose is oxidized via fat, about $15 \%$ of its available energy is lost. The approximately $400 \mathrm{~g}$ glycogen in the body could provide most of the energy supply for I d without any conversion to fat. (5) According to modern ideas the $\mathrm{P}: O$ ratio (the number of molecules of inorganic phosphate taken up to phosphorylate ADP, per atom of oxygen consumed) of mitochondrial oxidation is not absolutely fixed, so that there is scope for an increased yield of ATP per unit oxygen used. (6) There could be a decrease in substrate cycling (Newsholme \& Crabtree, 1976). According to the calculations of Reeds et al. (1985), such cycles may account for 10\% or more of energy turnover. (7) A final possibility is increased efficiency of ATP utilization in energy transduction. In the case of muscular contraction this would involve an increase in coupling efficiency.

When it comes to the energy cost of physical activity, there are again a number of possibilities for economy. At the biochemical level it appears that slow-twitch fibres are more efficient than fast-twitch fibres in terms of ATP used in relation to tension developed (Wendt \& Gibbs, 1978). Czech workers have found a greater mechanical efficiency of treadmill running in long-distance runners compared with football players (Bunc et al. 1984). Could this be that they have a different pattern of fibre types? It has been observed that in malnourished people the slow-type II fibres are selectively preserved (Russell et al. 1984). It is an interesting question whether adaptation to low-energy intakes could involve an alteration in the pattern 
of fibre types, favouring those that are more efficient. This would probably have to be genetically determined, since there is no evidence that such changes can be produced by training (Bassey \& Fentem, 198I).

Millward (1986) has proposed that changes in thyroid hormone activity may play an important part in adaptation to low-energy intakes. The relation of thyroid function to BMR is, of course, classical. Triiodothyronine $\left(\mathrm{T}_{3}\right)$ has an effect on the rate of whole-body protein turnover (Garrow, 1981; Wolman et al. 1986) and it influences the rates of both synthesis and breakdown of protein in muscle (Brown \& Millward, 1983). The work of Edelman (1974) showed the very important influence that thyroid activity has on the $\mathrm{Na}$ pump. A recent study shows that weight loss in obese patients reduces the $\mathrm{Na-pump}$ activity of leucocytes (Turaihi et al. 1986). Unfortunately, only recently has it become possible to measure plasma concentrations of free $T_{3}$ and thyroxine $\left(T_{4}\right)$, which are probably much more sensitive than the classical tests of thyroid function. To my knowledge, no measurements of this kind have yet been reported in people with a life-time's exposure to low-energy intakes.

Behavioural adaptations in physical activity may also be important, and by this I do not mean simply cutting out discretionary activities. Among behavioural adaptations I include adjustments in the rate of doing work. It has been accepted doctrine since the classical review of Passmore \& Durnin (1955) that, within limits, the energy cost of walking $\mathrm{I}$ mile is the same, whether one does it slowly or fast. However, values they quote show that this does not hold for people carrying loads. For example, for a man carrying $40 \mathrm{~kg}$, to walk $\mathrm{I} \mathrm{km}$ at $3 \mathrm{~km} / \mathrm{h}$ costs $335 \mathrm{~kJ}$ (80 $\mathrm{kcal}$ ) and, at $6 \mathrm{~km} / \mathrm{h}$ costs $460 \mathrm{~kJ}$ ( $110 \mathrm{kcal}$ ). On the other hand, calculation from the results of McDonald (Annex 3 of $\mathrm{FAO} / \mathrm{WHO} / \mathrm{UNU}$, I985) shows that to cover a given distance without a load, it would be $15-20 \%$ more efficient to walk at 100 $\mathrm{m} / \mathrm{min}$ than at $40 \mathrm{~m} / \mathrm{min}$. Thus the evidence is conflicting and the most economical rate of work clearly depends on the exact conditions. I am inclined to think that the rather slow rate of movement often observed in people in the tropics may not only be more comfortable in a hot climate but also more efficient, so that if time is not a limiting factor, this may be a way of saving energy. Related to this is the avoidance of unnecessary movements which, as Lawrence et al. (1984) noted, was very characteristic of the pregnant women whom they studied in The Gambia. These various possibilities for adaptation have been discussed in more detail elsewhere (Waterlow, 1986). They clearly have a very important bearing on the question of energy requirements.

Finally, it is appropriate to end by quoting from one of the greatest pioneers of nutritional physiology in our time, R. A. McCance. In a study on energy expenditure that he made with Booyens nearly 30 years ago (Booyens \& McCance, 1957) he noted wide variations between individuals in the energy expended on a given task, which could not be explained by differences in body-weight. Of cycling he said: ' $R M$ did this exercise with very little expenditure of energy. His sixteen-mile run in the country was taken in three stages on a circular course involving a long hill and a rise of $100-150$ feet and a descent against the wind on 
an exposed road. His expenditure on this run was lower than those of subject 7 or of $\mathrm{JB}$ cycling more slowly on the level. It is only fair to say that RM . . . is both a cyclist and a long-distance walker of great experience and has a highly developed sense of rhythm, and all unnecessary movements were probably eliminated from both occupations twenty-five years ago'.

\section{REFERENCES}

Bassey, E. J. \& Fentem, P. H. (1981). In The Principles and Practice of Human Physiology, pp. 19-130. [O. G. Edholm and J. S. Weiner, editors]. London: Academic Press.

Beaton, G. H., Milner, J., Corey, P., McGuire, V., Cousins, M., Stewart, E., de Ramos, M., Hewitt, D., Grambach, P. V., Kassim, N. \& Little, J. A. (1979). American fournal of Clinical Nutrition 32, 2546-2559.

Booyens, J. \& McCance, R. A. (1957). Lancet ii, 225-229.

Bray, G. A. (editor). (1979). In Obesity in America. Proceedings of the 2nd Fogarty Intemational Conference on Obesity. National Institutes of Health Publication no. 79. Washington, DC: US Department of Health, Education and Welfare.

Brown, J. G. \& Millward, D. J. (1983). Biochimica et Biophysica Acta 757, 182-19o.

Bunc, V., Sprynarova, S., Parizkova, J. \& Leso, J. (1984). Human Nutrition: Clinical Nutrition $3^{8 C}, 3^{17-319}$.

Dallosso, H. M., Murgatroyd, P. R. \& James, W. P. T. (1982). Human Nutrition: Clinical Nutrition 36C, 25-39.

Durnin, J. V. G. A. (1981). Basal Metabolic Rate in Man. Working Paper for foint FAO/WHO/UNU Expert Consultation on Energy and Protein Requirements.

Edelman, I. S. (1974). New England Fourmal of Medicine 290, $1303^{-1} 308$.

Edholm, O. G., Adam, J. M., Healy, M. J. R., Wolff, H. S., Goldsmith, R. \& Best, T. W. (1970). British fournal of Nutrition 24, 1091-1 107.

Eveleth, P. B. \& Tanner, J. M. (1976). Worldevide Variation in Human Growth. Cambridge: Cambridge University Press.

Food and Agriculture Organization/World Health Organization (1973). Energy and Protein Requirements. Technical Report Series no. 522. Geneva: WHO.

Food and Agriculture Organization/World Health Organization/United Nations University (1985). Energy and Protein Requirements. Technical Report Series no. 724, Geneva: WHO.

Garby, L. \& Lammert, O. (1984). Human Nutrition: Clinical Nutrition 38C, 395-397.

Garby, L., Lammert, O. \& Nielsen, E. (1986). Human Nutrition: Clinical Nutrition 40C, I4I-I 50.

Garrow, J. S. (1981). In Nitrogen Metabolism in Man, pp. 449-456 [J. C. Waterlow and J. M. L. Stephen, editors]. London: Applied Science Publishers.

Harries, J. M., Hobson, E. A. \& Hollingsworth, D. F. (1962). Proceedings of the Nutrition Society $21,157-168$.

Keys, A., Brozek, J., Henschel, A., Mickelson, O. \& Taylor, H. L. (1950). The Biology of Human Starvation. Minneapolis: University of Minnesota Press.

Lawrence, M., Singh, J., Lawrence, F. \& Whitehead, R. G. (1984). Nestlé Foundation Annual Report, pp. 43-52. Lausanne: Nestle Foundation.

Martorell, R. (1985). In Nutritional Adaptation in Man, pp. I3-29. [K. L. Blaxter and J. C. Waterlow, editors]. London: John Libbey.

Millward, D. J. (1986). In Proceedings of the XIII International Congress of Nutrition, Brighton, [T. G. Taylor, editor]. London: John Libbey (In the Press).

Newsholme, E. A. \& Crabtree, B. (1976). Biochemical Society Symposia 41, 61-109.

Norgan, N. G., Ferro-Luzzi, A. \& Durnin, J. V. G. A. (1974). Philosophical Transactions of the Royal Society B268, 309-348.

Passmore, R. \& Durnin, J. V. G. A. (1955). Physiological Reviews 35, 801-840.

Prentice, A. M. (1979). In Maternal Nutrition During Pregnancy and Lactation, pp. 167-183 [H. Aebi and R. G. Whitehead, editors]. Bern: Hans Huber. 
Prentice, A. M., Coward, W. A., Davies, H. L., Murgatroyd, P. R., Black, A. E., Goldberg, G. R., Ashford, J., Sawyer, M. \& Whitehead, R. G. (1985). Lancet i, 1419-1422.

Reeds, P. J., Fuller, M. F. \& Nicholson, B. A. (1985). In Substrate and Energy Metabolism in Man, pp. 46-57 [J. S. Garrow and D. Halliday, editors]. London: John Libbey.

Rhoads, G. G. \& Kagan, A. (1983). Lancet $\mathrm{i}, 492-495$.

Russell, D. McR., Walker, P. M., Leiter, L. A., Sima, L. L. F., Tanner, W. K., Mickle, D. A. G., Whitwell, J., Marliss, E. B. \& Jeejeebhoy, K. (1984). American fournal of Clinical Nutrition 39, 503-513.

Satyanarayana, K., Naidu, A. N. \& Narasinga Rao, B. S. (1979). American fournal of Clinical Nutrition 32, 1769-1775.

Schofield, W. N., Schofield, C. \& James, W. P. T. (1985). Human Nutrition: Clinical Nutrition 39C, Suppl. 1, 5-41.

Shetty, P. S. (1984). Human Nutrition: Clinical Nutrition 38C, 443-452.

Sukhatme, P. V. \& Margen, S. (1982). American fournal of Clinical Nutrition 35, 355-365.

Turaihi, T., Dandona, P. \& Baron, D. N. (I g86). Clinical Science 70, Suppl. 13, 52P.

Waterlow, J. C. (1986). Annual Reviews of Nutrition (In the Press).

Wendt, J. R. \& Gibbs, C. L. (1978). American fournal of Physiology 224, 1081-1086.

Whitehead, R. G. (1986). Proceedings of the Nutrition Society 45, 361-367.

Wolman, S. J., Sheppard, H., Fern, M. \& Waterlow, J. C. (1986). International Fournal of Obesity (In the Press). 